\title{
Drive for the divine
}

\section{Author: \\ Darryl Wooldridge ${ }^{1}$ \\ Affiliation: \\ ${ }^{1}$ School of Continuing \\ Theological Studies, \\ North-West University, \\ Potchefstroom Campus, \\ South Africa \\ Correspondence to: \\ Darryl Wooldridge \\ Email: \\ theosisone@gmail.com \\ Postal address: \\ Private Bag X6001, \\ Potchefstroom 2520, \\ South Africa \\ Dates: \\ Received: 08 Apr. 2015 \\ Accepted: 12 July 2015 \\ Published: 25 Sept. 2015}

How to cite this article:

Wooldridge, D., 2015, 'Drive

for the divine', HTS Teologiese

Studies/Theological Studies

71(3), Art. \#2997, 8 pages.

http://dx.doi.org/10.4102/

hts.v71i3.2997

\section{Copyright:}

C 2015. The Authors.

Licensee: AOSIS

OpenJournals. This work is

licensed under the Creative

Commons Attribution

License.

\section{Read online:}

Although the present article stands alone, it is a continuation of 'Living in the not-yet' (published in vol. 71, issue 1 of HTS). Both articles are derivatives of a larger study that discusses God as the centre of an often inarticulate and inchoate but innate human desire and pursuit to enjoy and reflect the divine image (imago Dei) in which every human being was created. The current article sets forth foundational considerations and speaks to the ineffaceable drive within humans to find God. It is a reciprocated drive - a response to God who first sought and continues to seek humans - a correlate and concomitant seeking in response to God. Although surely not the final word, this article discusses God as spirit and spiritual, by whom human beings have been created as imago Dei or God's self-address, showing God's heart as toward his creation, and humans most especially. Also discussed here is that humans are destined to join the perichoretic relationship that God has enjoyed from eternity. Moreover, in his ascension and glory, Jesus sends the Spirit of adoption into creation so that human creation might enter this same perichoretic relationship with God.

\section{Introduction}

There are eleven sections in this article. Anthropomorphism is inescapable, as God has, in parts, revealed himself by this manner for human understanding. Moreover, God's greatest revelation of himself is in the person of the man Jesus Christ. God accommodates himself (section three) to his creation and particularly to humans to facilitate perichoretic koinonia with them among the Trinity. In this fellowship the article is drawn into section four (Relationship) wherein God's heart is shown to be reaching and arranging for this much desired relationship with his creation. The introduction of interruptions to this desire is briefly discussed next. Although narrowly presented in section five (Best possible world), a full development and defence of worlds and the aetiology of evil are beyond the scope and intent of this article in the main. Certain conjectures are discussed and ostensibly founded as key to the intent and subject of this research in affecting proleptic, spiritual transformation (PrōST). For one, although human striving fails, and the finality of death is assured, God has created a world that cannot be defeated from God's purposes and intents (Lioy 2011:124). The creation into which humans have been placed is good and in truth the best possible world in God's sovereign, omniscient, and omnibenevolent desire (Leibniz 1998:123). Creation and most especially humans are intended for relationship with God.

Leibniz (1998:123) goes on to clarify that God is at full liberty and free to use his will and power without hindrance or compulsion by outside forces or wills. God is free in always being self-led toward what is good and right. He is without restriction or displeasure in prosecuting his will. In this all humans were created as God purposed in display of his wisdom and benevolence to best realise this wisdom and will. This 'need' of God, in freewill, is without imperfection as is the 'wrath' of God. However, this article does not hold to a 'Leibniz Lapse' that God could have created any possible world he might have wished (Plantinga 1974:44). If humans are to have freewill, as conjectured by this article, then they may, unlike God, by their free actions, introduce evil, pain, and suffering. Nevertheless, a drive for the divine (section six) cannot be snuffed out; in fact, the prior section supports such a drive. All persons have a divinitatis sensum (to sense divinity). Section seven necessarily speaks to the reality that God is spirit and spiritual, a necessary understanding for all who seek and approach him. The following is section eight (Trinitarian perichoretic relationship). In the perichoretic relationship is the enjoyment of community, the true freedom in its truth of love for which persons were created. God pronounced his creation as 'very good' (section nine), inclusive of this perichoretic relationship with humans who are given the privilege and responsibility of vicegerency. It is only as Homo imago Dei that this privilege and responsibility can be exercised (section ten). The conclusion (chapter eleven) of this article briefly reviews the full article and points to possible follow-on considerations and research. 


\section{The anthropomorphic God}

Not only are humans endowed with freewill, but also the imago Dei (central to God's creation of humans), which, especially as concluded in section eleven, now carries something more - the God-man. God's image in Jesus the Christ (imago Christi) now carries the existential realities of his incarnate life toward which PrōST (proleptic, spiritual transformation) drives in the now (Rm 8:29; 2 Cor 4:4; Col $1: 5)$.

In order to accomplish the goal of transformation, or unhindered and unveiled imago Dei, God had to put down human rebellion through the incarnation of Christ who exampled God's heart (anthropomorphically speaking) regarding the intended life meant for humans. Wherever, in this article, human form, characteristics, attributes, behaviours and functions are given as God's form, characteristics, attributes, behaviours and functions, they are used as an anthropomorphism (physitheism or anthropotheism), which is a literary device to describe God's condescension or accommodation in extending grace and mercy in relationship with humans. Beegle (1992:54) provides candid help in that the incarnational mediation of Jesus the Christ necessitates a measure of cautionary Christian anthropomorphism, for it is in this that the finite human can know something more of the infinite, incomprehensible God whose thoughts and ways are not the thoughts of his creatures. In particular, many Yahwist (J) passages are boldly anthropomorphic in expression (Von Rad 1972:26).

\section{Accomodatio}

Although God is infinite and incomprehensible, he accommodates himself to humans, the human situation, and human understanding, for example, by using anthropological language and analogy in order to reach humans within their own milieu and needs. Although elements of accomodatio (accommodation) can be found in the writings of Tertullian, Origen, and Clement of Alexandria, John Calvin is most recently better known (over a twenty-five-year rise [1952-1977]) for a fuller development of accomodatio, even conjectured as the heart of his theology (Wright 1997:18). This theological leaning is especially seen in Calvin's scriptural exegeses of related passages in such books as Genesis, Psalms, Ezekiel, Daniel, and John (Balserak 2006:8-9). So that God might be known by human beings, the thought of accomodatio presents the idea of God's condescension to human ways and means (e.g. Calvin 1996; Gn 1:5).

Some examples of God's heart in accomodatio include the following: God's heart is overflowing with love for his creation and creatures (Jn 3:16; Rm 5:8; 8:32; Eph 2:4; 1 Jn 4:9-10); God is desirous of beauty (Ps 8:1; 19:1; Ec 3:11a; Ac 14:17; 17:24; Rm 1:18-19) and of righteousness and justice (Gn 6:6-7; Ps 23:3; 89:14; 97:2); God's heart is for the disadvantaged, downtrodden, orphan, widow, poor, sick, possessed, dispossessed, all nations, children, women, men, animals, the planet, the universe, and all disadvantaged issues, situations and involved people (Mt 5:1-11; 11:5; Mk 1:40-41; 10:14; Lk 4:18; G1 3:8); God is for his kingdom (Dn 6:26; Mt 13:44-46; Jn 2:17); God is for the salvation of everyone (Jn 3:16; Rm 4:25; 5:8; 1 Cor 15:22; 1 Tm 2:6; 4:10; Tt 2:11; 1 Jn 4:9). Willard (1997:129-134) writes large and helpful words about God's heart as referenced above and that he is against idolatry, covetousness, irresponsibility, and a host of immoral and unrighteous actions and thoughts (Dt 4-5; 2 Ki 15:5; Mt 23:27-29; 2 Pt 2:9). It is toward such a heart that humans are drawn into relationship as imago Dei, reflecting back to God this same heart of love.

\section{Relationship}

From the beginning of the scriptural record, God displayed a heart and intent to share his essence with humanity as he created humans in his image and likeness and breathed into them his very life (Gn 2:7; Jn 5:21). Moreover, and to the point of this article, God's heart still yearns for a full, rich, and transformative relationship with humanity (Ps 34:8; Can 8:1; Jn 14:23; 17:21-23; Rm 12:2; 2 Cor 3:18; 6:16 [Grenz 2001:268; van Huyssteen 2006:118-123]).

God desires an intimate relationship with humans and is deeply troubled by any damage to that relationship (Lk 13:34; 19:41; Jn 11:33; 13:21). God's heart yearns to be in conversational relationship with humans, freely living in his will and glory (Ex 29:43-46; 33:11; Ps 23; Is 41:8; Jn 15:14; Heb 13:5-6 [Willard 1999:10]). In this desire, God's heart reached out to restore fallen humanity to relationship within the Triune, perichoretic community, other humans, and creation (Gn 3:8-11; Lv 26:12; Dt 23:14; 2 Cor 6:16). God's heart yearns to restore and deepen the rich and intimate, reciprocal conditions that he and other persons enjoyed as told in the story of Eden, as reflected in the Parable of the Prodigal Son (Gn 2; 3:6a; Lk 15:11-32), and as elevated in the life of Jesus Christ - 'You have heard it said, ... But I say to you ... ' (Mt 5:44). God desires fellowship and intimacy with humans enjoying and living out his image to the full beginning now (Aquinas 1981:885-886; Hagner 1993:134-136; van Huyssteen 2006:154, 157).

God's will is often referred to theologically as economy (Gk., oikovopía) or administration and is, at the basic level, simply God's heart and desire and how he arranges or pursues the fulfilment of that heart and desire. God's oikovoría, in creating such a world that is most conducive to his goals and means, is seen in the evolving and progressing world that humans inhabit. God's heart and desire are toward a world that is the best possible one that allows for the summum bonum of God's creation with human freewill seeking God (Augustine [1887] 2010; Brunner 2002:147; Leibniz 1998:123; Plantinga 1974:33, 54-55).

There is much in the human experience that would militate against such a conjecture as that presented above, such as mental and physical defect, prejudice, hegemony, discrimination, hate, murder, poverty, homelessness, 'natural' disaster, war, illness, malfeasance, and death. Although 
considered further below, a thorough examination of a coherent theodicy is beyond the scope of the present work. Nonetheless, this article holds that this world, as conceived by God, is in truth, the best catalyst for the spiritual transformation of free-willed human beings. It is designed, and has continued to develop, as the best soil and means to transformationally develop the heart of God in each individual human in expression of God's image and in proleptic, spiritual expression furthered below (Aquinas 1981:47).

\section{Best possible world}

It is not that God 'needs' evil to accomplish his intents with humans. Human freewill is needful to the full development of mature and transformed humans. A world in which humans are markedly free and thereby perform more good than evil, is of greater value than a world consisting of no free persons whatsoever (Plantinga 1974:30). Unfortunately, such freewill not only presents the opportunity for personal evil, but also, in fact, necessitates its actual introduction (Plantinga 1974:30-31). Even if such freewill (Augustine's improbra voluntas) potentiates and precipitates evil and suffering, a world in which such freedom is given, even if evil is consequential, is better for the development and transformation of humans. Whilst disagreeing with any ideation that God instituted evil (pain and suffering), whether often attributed to John Hick, the more narrowly held claim that challenges and temptations are inherently more valuable for developing virtues still holds more value than would any imagined ready-virtue apportioned to the individual.

Plantinga (1974:11), for one, gives trouble to the Irenaean or modern interpretation of his theodicy as provided in Hick when he allows that a theist may not be able to provide the rational and surely not a provable case as to why God allows evil, and yet it is not a contradiction in allowing that God does allow evil. It is beyond the purpose of this study to argue all of the causals and allowances driving evil proposed to be of God's means. However, John Hick would say, 'soul-making', a Keatsian coinage often used by Hick, is God's purpose in these difficulties in what this article refers to as the process of spiritual transformation. There is no contradiction in God's attributes of omnibenevolence and omnipotence in any of this.

In truth, such ready-made virtues displayed in spiritual transformation would be of no value having not been worked by trial and difficulty. Although Irenaeus' and Hick's freewill theodicy is severely questioned, and although such a theodicy is not required for the thesis of this study, the reality of this world in which trial, pain, sin, and evil, are clearly present make Hick's 'soul-making' or 'person-making' fruitful. This research deals with this postulate under the rubric of proleptic, spiritual transformation (PrōST). A world of both choice and God's sovereignty are presented throughout scripture and supported by this article. Again, consideration of the seeming tension between evil and an omnipotent loving God is briefly intermingled in this article (Collins 2000:156-157; Pannenberg (1997:165-166; Plantinga 1974:30).

\section{Drive for the divine}

Most particular to theodicy, and to the point of this study as discussed above, is that God desires vital and intimate relationship with transformed human beings in reflection of his Son. Although often obscured and buried deeply within the soul, this ultimate destination is known and resonates in the human heart. Catherine of Siena (1980) speaks to this love of God at a devotional level in The Dialogue (1980:325): 'Because you have fallen in love with what you have made!' This desire of God is the essential reason that human beings desire God in concordant, harmonious response, which response is, at its core, a reflection of God's desire (1 Jn 4:10, 19). It is a response, reflection, and echo of the very image of God, responding, reflecting, and echoing back to God and to the whole of creation (Ec 3:11). Within this transmission or transaction is the necessary and naturally spontaneous worship generated by such an encounter with the living God.

In consideration of this drive and encounter, Calvin (2006:43; Inst. 1.3.1) speaks about the semen religionis. God has deposited in all humans an understanding of 'his divine majesty' to prevent them, by this divine conviction, from hiding in ignorance. Specifically, Calvin (2006:43, 46, 47; Inst. 1.4.1) says, 'God has sown a seed of religion in all men' for divinitatis sensum (to sense divinity). He goes on to present the case that, although this seed resulting in a divine sense has been sown in humans, it does not ripen and certainly does not bear fruit in season. Humans struggle under vanity and an obduracy measuring God by their own standards and thereby missing how God has offered himself. They only seem as driven by their own machinations. So, human worship and service toward God is misplaced upon their own imagined goals driven by hearts not focused on and yielded to God.

In support of reformed epistemology, and Calvin in particular, Plantinga (1981:46) considers such ontological posits of God, and the present author believes, by inference, God's attributes (real desires among them), to be properly basic and justifiable even lacking any possible foundational argument within a normative contention pressing against such a belief (Plantinga 1981:42). God created homo sapiens in such a manner that they are inclined or disposed to see God's working in the universe, whether simple or grand (Plantinga 1981:46). Plantinga's argument is supportive of semen religionis no matter how distorted, misplaced, vain, or obdurate humans may be in obscuring the resultant divinitatis sensum.

Setting aside Plantinga for the moment and pressing against the restrictions of classic foundationalism, empiricism, and scientific reason, Milbank's (1998:123) rigorous, epistemic analysis of poesis, itself outside of accepted scientific postulation, unyieldingly suggests that in the 'poetic moment' is a realisation of the Beautiful. Here, in this aesthetic 
experience, is the place of the Christocentric revelation. It is 'a narrative projecting forward the divine horizon', experiencing this sacred narrative as Christ is supposed to have lived it (Milbank 1998:29). Persevering in this conjecture, and contrary to Milbank's resistance to a divine seed, one is drawn to this teleological eventuality. It seems appropriate to suggest that human understanding, based in mythos and mimesis (Milbank 1998:127) of Christ, becomes the 'mythos' that one encounters, driven by the semen religionis, and is drawn to and desirous of the divine in this divinitatis sensum exampled in Christ and implanted in all humans (Calvin 2006:43, 46, 47; Inst. 1.3.1). In speaking of mythos nothing is suggested or agreed that the present considerations, especially as they apply to Genesis 1 , are to be understood symbolically but rather as 'concentrated doctrinal content' and of topical interest for Israel then and all humans now (Von Rad 1972:47-48).

\section{Worship before farming}

Archaeologists have long believed that abundant vegetation and increasing wild game led to farming and domestication of animals which led to permanent settlements in turn leading to organised religion (Mann 2011:49). Recent archaeological findings have replaced this time-honoured, erroneous belief credited to V. Gordon Childe (Mann 2011:49). Beginning with geometric surveys, archaeologist Klaus Schmidt began unearthing the temple Göbekli Tepe in southern Turkey in 2003, which has been dated to 7000 years before the Great Pyramid of Giza, some 11,600 years ago (Mann 2011:39-40). Study of Göbekli Tepe has led to the firm belief that organised religion gave rise to farming. That is, religion, worship, and the spiritual preceded farming. The wonderment at changes in the natural world led to religion which led to the domestication of plants and animals, agriculture, and permanent settlement for the benefit of communal living and worship (Mann 2011:41-48). This discovery is significant in its suggestion that the intrinsic and overwhelming drive for the divine (divinitatis sensum) within humans is evidently responsible for community and progress in society as a display of imago Dei in the world. It is a response to divine general revelation and the God-infused impetus within humans as God-driven to seek the divine. Here relationship is born or at least shared in purpose among humans desirous of relationship with the divine and the transcendent.

The spiritual condition of human beings is often difficult to determine especially in the knowledge that much of the creation story has been made 'obsolete' by modern standards (Von Rad 1972:48). Nevertheless, the scriptures seem to tell a story about God's desire for intimate relationship with an image bearing from his creatures. Although not fully developed here, this desire does not imply any measure of anthropopathy and may be rendered will or wish ( $\theta \dot{\varepsilon} \lambda \omega$ [Gk.], Strong's 2309). A full discussion regarding the attributes of God is not within the scope of this article; however, anthropomorphisms are used in consonance with scripture.
Metaxas (2010:349) cites Dietrich Bonhoeffer when he wrote a circular to the local church in Finkenwalde, Germany in 1939 and said, 'Where God tears great gaps we should not try to fill them with human words'. Although speaking of the terrible loss of the war, the point applied here is not to avoid the issue, but that although God is not a man (Job 9:32; Rm 9:20), he often speaks of himself in human terms. What is more, not only does God speak of his 'desire', but makes plain that without the satisfaction of his desire for the divine in resonance with God's desire for humans there is no human fulfilment. Thus, without this resonance humans cannot find fulfilment or satisfaction, and therefore, remain frustrated from God as their 'source' (Houston 1992:241-242). God's desire or will that humans be holy, in fellowship with him, follow his commandments, and a host of other intents and directions for humans, speaks to God's desire and will for humans in harmonious communion (Gn 3:9; Lv 26:12; 1 Jn 4:19; 1 Pt $1: 16)$. Moreover, there is no implication of any ontological lack in God's being by such a desire any more than that God desires all to be saved (1 Tm 2:3-4). The psalmist calls out from this desire:

Whom have I in heaven but you?

And there is nothing on earth that I desire besides you.

My flesh and my heart may fail,

but God is the strength of my heart and my portion forever. (Ps 73:25-26)

The New Testament reflection and progression of the psalmist's heart and desire in response to God's heart and desire can be found in the apostle Paul's words about Christ to the Philippians. In Christ one comes to know God the Father (Jn 14:7-11; Col 1:15-20). So then, to know Christ Jesus is to know God the Father and to satisfy God's and one's own heart's desire. Indeed, everything should be seen as loss because of the incredible worth of knowing Christ Jesus the Lord. For his sake one should be willing to suffer the loss of everything and count it all as waste, in order to gain Christ and be found in him, not having one's own inadequate righteousness, a righteousness that comes from the law, but a righteousness that comes through faith in Christ, the righteousness from God contingent on faith - that one may know him and the supremacy of his resurrection now, and may now share his sufferings and tribulation, becoming like him in his death, that by any means possible one may enjoy the resurrection from the dead (Phlp 3:7-11; Hooker 2000:526-529).

\section{Spirit and spiritual}

A clear understanding about whom or what God is, as discerned from God's self-revelation, is essential to understanding God's heart and human reciprocity. It is necessary for any understanding or theology about human spirituality (Chan 1998:40). This notion is particularly important to this brief article. An understanding of God as spirit and being spiritual is central. Furthermore, God must be an ontological entity capable, available, responsive, and desirous of relationship with human beings for any hope of 
intimate encounter with him. This might seem troublesome since God is spirit, unsearchable, inscrutable, unseen, and dwells in unapproachable light (Ps 145:3; Jn 6:46; 2 Cor 3:17; 1 Tm 1:17; 6:16; Gn 1:2b; 1 Ki 8:27; Is 55:8; Jn 3:6, 8; 4:24; 1 Jn $4: 12)$.

Moreover, God is not like any material, anti-material, energy, vapour, or space, but rather 'the fullness or essence of being' or simply 'pure being' (Grudem 1994:188). God's being is spiritual, and God acts from that centre (1 Cor 2:13; 10:4). Moreover, God cannot be contained at any point of the created or uncreated (Ps 139:7-10; Is 66:1) and forbids images and representations of himself to suggest he is limited by form or place or material things that are reflected by a body of some fashion (Ex 20:4; Is 40:18, 25). God is that being than which nothing greater can be conceived' (Fairweather 1956:75).

As a spiritual being, God is invisible (Jn 1:18; 1 Tm 1:17; 6:16). Regarding spiritual matters, it more deeply has to do with his inaccessibility without his willed revelation and manifestation (incarnation) toward creatures that are capable of discerning his advances toward them. This suggests God not as an obscurant being but rather above human self-willed scrutability (Moltmann 1993a:220-221; Von Rad 1972:25-26).

In discussing how Karl Barth was influenced by Søren Kierkegaard's thoughts about divine transcendence, Millard Erickson (2013:284-285) borrows the phrase 'qualitative distinction and dimensional beyondness' from Martin Heinecken, wherein this distinction and beyondness are the qualitative differences between God and humans and thus the inaccessibility of God by humans. Such distinction exacerbates the inscrutability of God and assures God's invisibility. However, accepting this understanding does not negate the availability of a condescending and therefore immanent God. God is near and available (Job 12:10; Ac 17:28; Rm 10:8; Heb 7:25) notwithstanding his qualitative distinction.

\section{Trinitarian perichoretic relationship}

Trinitarian theology demonstrates that God is not near and available, but that God is spirit and spiritual but also in three persons, Father, Son, and Spirit, who are in a perfect and unique relationship of divine love within the perichoretic union of the Trinity (Moltmann 1993a:258). Christian philosopher and martyr Boethius (c. 480-525) says that the nature of a person is its irreplaceable substance. Moltmann (1993b:172) juxtaposes this notion against Augustine's thoughts on relationship and concludes that each of the Trinity possess the 'same individual, indivisible and one divine nature' in varied ways, the Father of himself and the Son and Spirit from the Father. So then, they are independent in their divinity but profoundly constrained and dependent on one another. It follows from this that, Moltmann claims, personality and relationships are connected and present simultaneously. The Trinity subsists in 'the common divine nature' and the Trinity 'exists in relations to one another' (Moltmann 1993b:173). In truth, to be a person, as is each of the Trinity, is to be in and moulded by relationship 'in accordance with the relational difference' and not constituted by the relationship but rather presupposed in it (Moltmann 1993b:172) (cf. Wooldridge \& Lioy 2015).

In applying this concept to the Trinity, Moltmann (1993b:171) speaks of that which is 'noninterchangeable, untransferable individual existence in any particular case'. Moltmann brings Hegel into the discussion to join Boethius and Augustine in that the Trinity realises within its self one another in love. By this third contribution, Moltmann (1993b:174) speaks of three terms into the doctrine of the Trinity: (1) person, (2) relations, and (3) history of God. Moreover, God's 'plural deliberation', that is in relation to himself, is singular in the plural and plural in the singular, and inferentially, humans are both singular and plural inversely. In this God has his correspondence of or in human community individually and especially in unity (Moltmann 1993a:117-118).

Although Moltmann mistakenly limits this community to the male-female relationship, van Huyssteen (2006:138) presses that the image of God cannot be summed up as the relationship between a man and woman. Male and female, in Genesis, simply indicate relationship. Moltmann (1993a:220-221) does allow that human likeness to God in the whole human existence as consisting in correspondence and relationship to the perichoretic God as revelation of the divine in earthly form. Although differing with Moltmann (1993a:222-223) here in his insistence on the male-female image of God on earth, it is manifest that God's image can only fully be lived in full human expression in community as social beings. Also as discussed below, the male-female reality is necessary in reflection of continued creation by God's vicegerents. Incredibly, the perichoretic relationship reaches to all creation and includes it without necessitating creation's divinisation although allowing creation's influence upon the Godhead (Moltmann 1993a:258). From this perichoretic relationship and human imago Dei flows 'mutual need and mutual interpretation. The true human community is designed to be the imago Trinitatis'.

As 'plastic image' or 'God's sovereign emblem' (Von Rad 1972:60) humans not only function as God's representatives, but also reflect God in the ontology of being in which there is a draw to be in and to express this perichoretic relationship. Not only should humans be in relationship with one another, but also with God. God, as revealed in the scriptures, is a personal God desirous of intimate relationship with his creation (Chan 1998:41). God desires humans to be like himself; therefore, he created them to be such (Lv 11:44-45; Jn 17:11, 21; Rm 8:29; 1 Pt 1:14-16). In addition to creating beings as imago Dei, God also brings the fullness of this to fruition through a process of spiritual transformation in perichoretic relationship. Spiritual transformation is a determinant of material persons' ability to relate at some significant level with an immaterial and spiritual being and the ability of 
these material persons to 'see' this self-same immaterial, spiritual, and invisible God, whomever may be initiating the encounter (Pannenberg 1994:224).

Not arguing the filioque here, Moltmann (1993b:127) speaks of two movements of God in which the first, 'the divine Trinity throws itself open', the Father having sent the Spirit of God through the Son, that is, the Spirit of God and the Spirit of Christ open to the world in time and to renew and unite in whole all of creation. The second movement is reversed from the first. In the transformation of the world in and through God the Spirit, all turns to God. Being moved by the Spirit, all comes to the Father through Jesus Christ the Son. By the glorification of the Spirit, the world, times, people, and things are brought together before the Father and become his.

In the first movement God reached out to his creation, and in the second movement the creation is brought to God. Both movements are in the Son through and by the Spirit in full glorification of the Trinity. Later in this same work, Moltmann (1993b:176) speaks of the manifestation of the perichoresis (Gk.) of divine life in glory as reaching further Trinitarian manifestation or relations. It is the glorification of the Spirit of God in 'the experience of salvation'. The depth of such an experience of salvation in the Trinity is enjoyed in the perichoretic relationship of Trinity drawing and welcoming humans into this same reality. Most fully, Moltmann (1993b:213) says, this salvation and relationship will culminate as people becoming God's dwelling and home. The early church looked to an eschatological kingdom of glory in which all would be deified (Gk., $\theta \varepsilon \dot{\varepsilon} \omega \sigma \iota)$ ). It is a kingdom in which people will be finally and completely drawn into the eternal life of the triune God.

Humans, constituted in part as spiritual beings, were created to experientially enjoy a spirituality that is living for God through Christ, in full communion, presence, and by the power of the Spirit of God (Downey 2003:258). Here in this perichoretic relationship, in the enjoyment of community, is found the true freedom in its truth of love for which persons were created $-\mathrm{a}$ 'project of the future' that transcends the present and moves toward the direction of God's future 'the history of the kingdom of God' (Heschel 1943:120; Moltmann 1993b:216-217, 221) that nurtures proleptic, spiritual transformation (PrōST). Admittedly, these points are not all-inclusively developed here; however, they serve appropriately to reflect the progressive Trinity in internal relationship and to humans, especially God's friends.

\section{Very good}

God's satisfaction and regard for the created universe, and humans particularly, was exceptional as noted at the end of the creation story in which God pronounced his doing in creation and the outcomes as 'very good' (Gn 1:31). This was also inclusive of the above sought perichoretic relationship. Pointing out the significance of human creation, Von Rad (1972:57) notes that three times in verse 27, God created
(Heb., bārā) in reference to humans, both singular and collective. This refrain points up 'the fullest significance for that divine creativity which is absolutely without analogy'. The beauty of this enterprise is 'completely perfect' in wonderful purpose and harmony (Von Rad 1972:61).

That which was very good, was inclusive of humans created very much like God for fellowship. God formed the entire created order of things culminating as goodness inclusive of human beings created in God's image. This world, as 'very good' is the environment into which humans were conceived for God's intent of obedient, worshipful, and glorifying communion with himself. These persons were constituted with bodies as living souls inclusive of relationship, representation, and essence (Gn 2:7 [Heb., nepesh]; 1 Cor

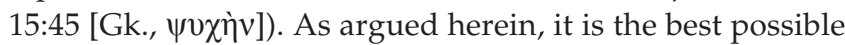
world in which to mature humans to a full expression of imago Dei. No doubt, the goodness of God's creation is in part simply because God created it (Ps 119:68; 1 Tm 4:4). By definition, whatever God does must be particularly, essentially, and consequentially or teleologically good, if God is beneficent and in no way maleficent. Finally, to have humans created in God's image as the capstone to creation is to survey the whole in satisfaction, which brings a pronouncement of 'very good' in reflection of God's heart (Von Rad 1972:57, 61).

God communicated attributes to humans such as love, mercy, grace, benevolence, and intellect. Even the physicality of humans seems to be included in this goodness, for humans were given corporeal bodies and directed to rule over the physical earth in their bodies and to procreate in those same physical bodies (Gn 1:228; 2:7). Von Rad (1972:58-59) concurs; the wonderment of the human physical appearance is not a development exempted from the domain and concept of God's image and should not be lessened by spiritualisation or any kind of intellectual proclivity. The whole human - his or her totality - is created in God's image. It is not exact to speak of God in anthropomorphic terms, but rather to speak of humans as theomorphic (Von Rad 2001:145). Eventually, these worthy human bodies will be resurrected into glory (1 Cor 15:52; 1 Th 4:15-18). This goodness is inclusive of God's image in humans as not simply one but complete expressions of God's full spectrum of communicable image, such as the substantive, relational, and functional aspects of image. This is even shared in human beings created as male and female to share in God's creative ability in procreation as a special blessing (Von Rad 1972:60-61).

The goodness of God's creation and of humans within that creation is evident in God's thrice pronouncement of his incomparable creation (Heb., bārā) in Genesis 1:27, culminating in humankind, his intent and direction from the first verse (Von Rad 1972:57). In the creation of God, humans have been entrusted with its care (Gn 1:26, 28; Job 5:9; 37:14). Moreover, humans are to continue the responsibility for creation as vicegerents responsible to God (Ps 8:6). 
This vicegerency is more poignant when viewed through the agencies of genealogy and benefice. Humans are children, sons, heirs of God, fellow heirs with Christ, and eventually glorified with Christ (Rm 8:17; Gl 3:29; 4:7; Eph 3:6). God's intent is seen early in that he delegated his sovereign right to his first created human as a 'worthy assistant' with a task to give names to the world's creatures and to rule over them (Gn 2:19; Von $\operatorname{Rad} 1972: 53,59,83)$. As with powerful earthly sovereigns, humans are God's sovereign emblems to represent God in relation with God in all earthly affairs (Von Rad 1972:60). Moreover, one might infer or receive a hint at the possibility of the fall in the freewill that was given humans in vicegerency introducing rebellion in to the created order. Included in this ground of goodness (or best possible world) is the opportunity for self-willed rebellion that, as shown above, also serves the transformation of humankind (Plantinga 1974:29-30, 44; Willard 1999:10).

Not only was creation declared very good in scripture, but numerous philosophers and theologians have argued and debated that this is the 'best of all possible worlds' (Steinberg 2007:123-124). This best of all possible worlds has importance in that it is the environment into which God's creatures would be situated, tested, offered abundant life, and transformed into God's inclusive, unhindered expressed-image. The nature of humans is indeed wonderful and awesome (Von Rad 1972:57-60). If it were not so, God could not have become incarnate. It may even be that flesh was elevated by incarnation. In either case, God's remedy testifies to the nobility of the human being in the incarnation (Ranft 2013:5, 165-166).

\section{Imago Dei}

As addressed above, the human image of God (Homo imago Dei), generally referred to in this article as imago Dei, with vicegerency responsibility, is a discussion of great consequence not only to the premise of this research but also to anyone seeking understanding and meaning in this life. The imago Dei is foundational to all divine revelation (Feinberg 1972:236). A postfoundational strategy for revisionist interpretations that sympathises and rings true with core scriptural texts, in a shift away from speculation and abstraction, ushers the understanding of imago Dei into a theological and interdisciplinary dialogue (van Huyssteen 2006:151). More specifically, God's image in humans is central to this study of proleptic, spiritual transformation (PrōST).

Since this is the case, it is vital that this study is founded in a coherent theory of the imago Dei. This research sets aside any Platonic, mediaeval, or Aristotelian beliefs that may place the human parts in conflict with each other pressing for supremacy or set against recognising the whole human, spirit, soul, and body, as the full embodiment of the imago Dei (Moltmann 1993a:245) as God's self- address. This integratedembodiment is the hoped-for consummation of the human life in reflection of the completed life of the God-man Jesus Christ.
Admittedly, such an embodiment is, in its full transformation, magnificent, and its effulgence emanates light making the sun seem dark in comparison (Gottstein 1994:173-174). The imago Dei is a sign of humanity's gravitas, beauty, and original androgyny - the Adam Qadmon or Primordial human being (Feinberg 1972:241). Humans are, by this view, complete, integrated, and without partitioning. Such wholeness is animated by God's breath (Gn 2:7).

\section{Conclusion}

An exhaustive treatment of the vast proposals and arguments related to this subject are not necessary, neither possible here except as begun. This article spoke to the verygood world into which God created and made humans with an ineffaceable drive within them as God's children and vicegerents of this planet to find, serve, worship, love God, and to care for the creation. God created the very best possible world with the means for human freewill seeking and transformation.

As a result of the lawlessness of sin brought on through human freedom, God needed to intervene (incarnation) in order to put down the rebellion that had, to some measure, veiled the imago Dei in human beings and created estrangement of humans from God. It, Imago Dei, or God's self-address now carries something more - the God-man (imago Christi). God's image in Jesus the Christ, as bestowed to humans by the Spirit of God, now carries the existential realities of his incarnate life, passion, resurrection, and ascension.

Although surely not the final word on this subject, this article discussed God as spirit and spiritual by whom humans have been created as imago Dei. It spoke about God's heart in seeking to fully recover and express his image in humanity through proleptic, spiritual transformation (PrōST) in perichoretic relationship as the remedy to the spiritual effects of the fall. It is a reciprocated drive - a response from humans to God who first sought and continues to seek humans - a correlate and concomitant seeking in response to God.

\section{Acknowledgements Competing interests}

The author declares that he has no financial or personal relationships which may have inappropriately influenced him in writing this article.

\section{References}

Aquinas, T., 1981, The Summa theologia, 5 vols., transl. Fathers of the English Dominican Province, 2nd rev. edn., Christian Classics, Westminster.

Augustine, [1887] 2010, On Christian doctrine, transl. J. Shaw, NPNF ${ }^{1}, 14$ vols., Philip Schaff (ed.), Christian Literature Publishing Co., Buffalo, NY - Revised and edited for New Advent by Kevin Knight, viewed 10 September 2011, from http://www. newadvent.org/ fathers/12020.htm

Balserak, J., 2006, Divinity compromised: A study of divine accommodation in the thought of Calvin, Studies in early religious reforms, Springer, Dordrecht.

Beegle, D.M., 1992, s.v. 'Anthropomorphism', in W.A. Elwell (ed.), Evangelical dictionary of theology, Baker, Grand Rapids, MI, p. 54.

Brunner, E., 2002, Man in revolt: A Christian anthropology, Lutterworth Press, Cambridge. 
Calvin, J., 1996, Commentaries on the first book of Moses called Genesis, translated from the original Latin, and compared with the French edition, by the rev. John King, M.A. of Queen's College, Cambridge, incumbent of Christ's Church, Hull, King, M.A., of Queen's College, Cambridge, incumbent of Christ's Church, Hull,
vol. 1, Christian Classics Ethereal Library, Grand Rapids, MI, viewed 04 February 2012, from http://www.ccel.org/ccel/ calvin/calcom01.txt

Calvin, J., 2006, Institutes of the Christian religion, 2 vols., ed. J.T. Mitchell, Library of Christian classics, Westminster John Knox Press, Louisville, KY.

Chan, S., 1998, Spiritual theology: A systematic study of the Christian life, InterVarsity Press, Downer Groves, IL.

Collins, C.J., 2000, The God of miracles: An exegetical examination of God's action in the world, Crossway Books, Wheaton, IL.

Downey, M., 2003, The upper room dictionary of Christian spiritual formation, ed. K. Beasly-Topliffe, Upper Room Books, Nazhville, TN.

Erickson, M.J., 2013, Christian theology, 3rd edn., Baker Academic, Grand Rapids, MI.

Fairweather, E.R. (ed. and transl.), 1956, A scholastic miscellany: Anselm to Ockham, Library of Christian classics, Ichthus edition, Westminster Press, Philadelphia, PA.

Feinberg, C.L., 1972, 'The image of God', Bibliotheca Sacra 129, 235-246, viewed 26 August 2011, from http://faculty.gordon.edu/hu/bi/Ted Hilderbrandt/ OTeSources/01-Genesis/Text/ Articles-Books/Feinberg-Image-BS.pdf

Gottstein, A.G., 1994, 'The body as image of God in rabbinic literature', Harvard Theological Review 87(2), 171-195. http://dx.doi.org/10.1017/ S0017816000032776

Grenz, S., 2001, Social God and the relational self: A trinitarian theology of the imago Dei, Westminster John Knox Press, Louisville, KY.

Grudem, W., 1994, Systematic theology: An introduction to biblical doctrine Zondervan, Grand Rapids, MI.

Hagner, D.A., 1993, Matthew 1-13, Word Books, Dallas, TX; Nelson Reference \& Electronic, Nashville, TN. (Word biblical commentary, vol. 33a).

Heschel, A.J., 1943, 'The holy dimension', Journal of Religion 23(2), 117-124.

Hooker, M.D., 2000, Letter to the Philippians, Abingdon Press, Nashville, TX. (New Interpreter's Bible, vol. XI).

Houston, J., 1992, The heart's desire: A guide to personal fulfilment, Lion Publishing, Oxford.

Leibniz, G.W., 1998, Theodicy: Essays on the goodness of God, the freedom of man and the origin of evil, Open Court, La Salle.

Lioy, D., 2011, Evolutionary creation in biblical and theological perspective, Studies in biblical literature, vol. 148, H. Gossai (gen. ed.), Peter Lang, New York, NY.
Mann, C.C., 2011, 'Every now and then the dawn of civilization is reenacted on a remote hilltop is southern Turkey', National Geographic Magazine 219(6), 34-59.

Metaxas, E., 2010, Bonhoeffer: Pastor, martyr, prophet, spy, Thomas Nelson, Nashville, TN.

Milbank, J., 1998, The word made strange: Theology, language, culture, Blackwell, Malden, MA.

Moltmann, J., 1993a, God in creation: A new theology of creation and the Spirit of God, The Gifford Lectures, 1984-1985, Fortress Press, Minneapolis, MN.

Moltmann, J., 1993b, The Trinity and the kingdom: The doctrine of God, Fortress Press, Minneapolis, MN.

Pannenberg, W., 1991, 1994, 1997, Systematic theology, vols. 1-3, Eerdmans, Grand Rapids, MI.

Plantinga, A.C., 1974, God, freedom, and evil, Eerdmans, Grand Rapids, MI.

Plantinga, A.C., 1981, 'Is belief in God properly basic?', Noûs 15(1), 41-52.

Ranft, P., 2013, How the doctrine of the incarnation shaped Western culture, Lexington Books, Plymouth.

Siena, C. of, 1980, Catherine of Siena: The dialogue, Classics of Western spirituality, Paulist Press, Mahwah, NJ.

Steinberg, J.R., 2007, 'Leibniz, creation and the best of all possible worlds', International Journal for Philosophy of Religion 62(3), 123-133. http://dx.doi. org/10.1007/s11153-007-9136-7

Van Huyssteen, J.W., 2006, Alone in the world?: Human uniqueness in science and technology, Eerdmans, Grand Rapids, MI.

Von Rad, G., 1972, Genesis: A commentary, transl. J.H. Marks, Westminster Press, Philadelphia, PA. (The Old Testament Library).

Von Rad, G., 2001, Old Testament theology, vol. 1: The theology of Israel's historical traditions, transl. D.M.G. Stalker, Westminster John Knox Press, Louisville, TN. (The Old Testament Library).

Willard, D., 1997, The divine conspiracy: Rediscovering our hidden life in God, HarperCollins, New York, NY.

Willard, D., 1999, Hearing God: Developing a conversational relationship with God, InterVarsity Press, Downers Grove, IL.

Wooldridge, D. \& Lioy, D., 2015, 'Living in the not-yet', HTS Teologiese Studies/ Theological Studies 71(1), Art. \#2100, 9 pages. http://dx.doi.org/10.4102/ hts. v71i1.2100

Wright, D.F., 1997, 'Calvin's accommodating God', in W.H. Neuser \& B.G. Armstrong (eds.), Calvinus sincerioris religionis vindex, Papers of the Sixth International Congress on Calvin Research (Edinburgh, Scotland, 1994), pp. 3-19, Sixteenth Century Journal Publishers, Kirksville, MN. 